\title{
Rapid Differentiation of Candida albicans from Non-albicans Species by Germ Tube Test Directly From Blood Culture Bottles
}

\author{
Kan Kültür Şişesinden Direkt Germ Tüp Testi ile Candida albicans/Non-albicans Hızlı Ayrımı
}

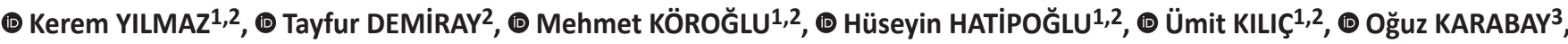 \\ (D) Mustafa ALTINDiş 1,2 \\ 1 Sakarya University Faculty of Medicine, Department of Medical Microbiology, Sakarya, Turkey \\ 2Sakarya University Training and Research Hospital, Laboratory of Medical Microbiology, Sakarya, Turkey \\ ${ }^{3}$ Sakarya University Faculty of Medicine, Department of Infectious Diseases and Clinical Microbiology, Sakarya, Turkey
}

\section{Abstract}

Introduction: It is important to identify infection-causing yeasts rapidly and perform antifungal susceptibility tests in order to determine the treatment to be applied. The aim of this study was to use direct germ tube test (GT) from blood culture bottle for rapid differentiation of albicans/ non-albicans Candida species to evaluate the possble contribution of this test to the implementation of earlier and narrower-spectrum antifungal therapy compared to conventional methods.

Materials and Methods: This 4-years retrospective study included 129 positive automated blood culture samples with yeast detected in Gram staining among 11,080 blood cultures obtained from inpatients in various wards. GT was performed directly from these bottles. All isolates were identified by VITEK (bioMérieux, Marcy-l'Étoile, France) and antifungal susceptibility tests were performed with the VITEK $2^{\circledR}$ automated system (bioMérieux, Marcy-l'Étoile, France).

Results: Candida albicans was identified as the causative agent in 57 (44.2\%) of the 129 blood cultures with direct Gram staining from the bottle. Conventional GT was positive for all C. albicans isolates (100\%), while direct GT from blood culture bottle was positive in 54 (94.73\%). Direct GT from blood culture yielded false-negative results in the remaining three samples (5.27\%). There was 97.6\% (126/129) agreement between conventional GTT method and direct GT from blood culture bottle. Non-albicans Candida species were isolated from the 72 samples with negative direct GT from blood culture bottle (43 C. parapsilosis, 17 C. tropicalis, 7 C. famata, 4 C. glabrata, and 1 C. lipolytica). Conventional GT results were also negative for all of these isolates.

Conclusion: Direct GT from positive blood cultures that are shown to contain yeast by Gram staining enabled differentiation of albicans/nonalbicans Candida species one day earlier than conventional culture. This method shows a high agreement rate with conventional diagnostic tests. It should be kept in mind that false negative results may be obtained at very low rates. This test may be helpful for initiation of a more appropriate empirical antifungal treatment. Furthermore, it is easy and can be applied in all clinical microbiology laboratories.

Keywords: Diagnostic performance analysis, blood stream infections, candidemia yeasts, identification

\section{Öz}

Giriş: Enfeksiyon etkeni olan mayaların çok hızlı bir şekilde tanımlanması ve antifungal duyarlılık testlerinin yapılması, uygulanacak tedavinin belirlenmesi açısından önemlidir. Bu çalışmada, kan kültür şişesinden direkt germ tüp testi (GTT) ile hızlı bir şekilde albicans/non-albicans Candida türlerinin ayrımı yapılarak, bu testin erken ve daha dar spektrumlu antifungal tedavinin uygulanmasına olası katkısının konvansiyonel yöntemlerle kıyaslanarak araştırılması amaçlanmıştır.

Gereç ve Yöntem: Bu dört yıllık retrospektif araştırmada, çeşitli kliniklerde yatan hastalardan alınan toplam 11.080 kan kültürü içerisinden otomatize kan kültürü cihazında pozitif sinyal alınan şişelerden yapılan Gram-boyamada maya saptanmış olan 129 örnek incelenmiştir. Bu şişelerden direkt GT yapılmıştır. Tüm izolatların identifikasyonu cihazı (bioMérieux, Marcy-l'Étoile, Fransa), antifungal duyarlılık testleri ise VITEK $2^{\circledR}$ otomatize sistemi

Cite this article as: Yılmaz K, Demiray T, Köroğlu M, Hatipoğlu H, Kılıç Ü, Karabay O, Altındış M. Rapid Differentiation of Candida albicans from Non-albicans Species by Germ Tube Test. Directly From Blood Culture Bottles and Early Candidiasis Treatment. Mediterr J Infect Microb Antimicrob. 2019;8:37. 
(bioMérieux, Marcy-l'Étoile, Fransa) ile yapılmıştır.

Bulgular: Şişeden yapılan direkt Gram-boyamada maya hücresi görülen 129 adet kan kültüründen 57'sinde (\%44,2), üreyen etkenin Candida albicans olduğu saptandı. C. albicans olduğu saptanan izolatların tümünde konvansiyonel GT'nin de pozitif olduğu görüldü. Bunların 54'ünde (\%94,73) kan kültür şişesinden yapılan direkt GT'nin pozitif olduğu saptandı. Geriye kalan üç $(\% 5,27)$ örnekte kan kültür şişesinden yapılan direkt GT'nin yanlış negatif sonuç verdiği belirlendi. Konvansiyonel GT yöntemi ile kan kültür şişesinden direkt yapılan GT arasında \%97,6 (126/129) oranında uyum olduğu görüldü. Kan kültür şişesinden yapılan direkt GT yöntemi ile negatif sonuç alınan 72 örnekten non-albicans Candida türleri ürediği (43'ü C. parapsilosis, 17'si C. tropicalis, 7'si C. famata, 4'ü C. glabrata ve 1'i C. lipolytica) saptandı. İzolatların tümünde konvansiyonel GT yönteminin de negatif sonuç verdiği görüldü.

Sonuç: Pozitif sinyal sonrasında kan kültür şişesinden yapılan Gram-boyamada maya görülen şişeden direkt GTT yapılması; albicans/non-albicans Candida türleri ayrımının kültürden bir gün önce tespitine olanak sağlamaktadır. Bu test konvansiyonel tanı testleri ile yüksek uyum oranı göstermektedir. Buna karşı çok düşük oranda yanlış negatif sonuçlar alınabileceği akılda tutulmalıdır. Direkt Gா daha erken ve uygun antifungal ajan ile ampirik antifungal tedavi başlanabilmesine yardımcı olabilir. Ayrıca bu yöntem; kolay ve bütün klinik mikrobiyoloji laboratuvarlarında uygulanabilirdir.

Anahtar Kelimeler: Diagnostik performans analizi, kan dolaşımı enfeksiyonları, kandidemi, maya, identifikasyon

\section{Introduction}

Candidemia is associated with high mortality rates and prolonged hospital stay ${ }^{[1]}$. This infection poses a serious risk for patients in intensive care units, immunocompromised patients, and patients receiving long-term antibiotherapy ${ }^{[2]}$. Candida albicans is a member of the normal flora of the skin, oral cavity, intestines, and vagina. It is also the leading cause of candidemia ${ }^{[3]}$. However, non-albicans Candida infections are responsible for a substantial and growing proportion of all Candida-related bloodstream infections. The most common agents in non-albicans Candida infections are $C$. tropicalis, $C$. parapsilosis, C. glabrata, and C. krusei ${ }^{[4]}$. In addition, due to their tendency to form biofilms on foreign body surfaces, they may cause treatment-resistant catheter-related infections in catheterized patients, especially those in intensive care units ${ }^{[5]}$.

Candida species comprise 7-10\% of the bloodstream infections in intensive care units ${ }^{[6]}$. Rapid clinical response can be achieved with expeditious identification of the agent and appropriate antifungal therapy ${ }^{[7]}$. C. albicans isolates are generally susceptible to the azole class of antifungal drugs. However, non-albicans Candida species may be resistant to azole antifungals. The inappropriate but widespread use of azoles for the treatment of bloodstream infections caused by non-albicans Candida species may result in the increment of resistant Candida strains or the development of resistance during treatment $t^{[8]}$. Hence, identifying the causative Candida species and performing antifungal susceptibility tests are imperative when managing Candida bloodstream infections ${ }^{[9]}$.

Since waiting for the results of yeast identification and antifungal susceptibility testing may lead to unacceptable outcomes, empirical antifungal therapy must be initiated immediately in clinical practice. To this end, it is necessary to identify the causative yeast very quickly and to perform antifungal susceptibility tests ${ }^{[0]}$. However, this cannot be performed in every laboratory. A period of about 24-48 hours is required to detect yeast growth in medium. This step delays obtaining a result for rapid diagnosis. The germ tube test (GT) is a fast, simple, and inexpensive test used in clinical microbiology laboratories to distinguish between albicans and non-albicans Candida species. Performing GT directly from positive blood culture bottles via various modified methods is also used, which further enables rapid appropriate treatment ${ }^{[10]}$. However, there are few publications on this subject and there is no modified procedure where a centrifuge step is added while performing GT directly on the sample taken from the blood culture flask. The aim of this study was to rapidly distinguish between albicans/non-albicans Candida species with direct GT from blood culture vials.

\section{Materials and Methods}

\section{Sample Collection and Ethics Committee Approval}

This study was approved by the Ethics Committee of Sakarya University Medical Faculty (approval no:71522473/050.01.04/67). A total of 11,080 blood culture samples taken from inpatients in various wards of the Sakarya University Training and Research Hospital between January 1, 2015 and December 31, 2018 (4 years) were evaluated. Of these, 129 vials that tested positive in the automated blood culture device (BacTAlert 3D, bioMérieux, Marcy-l'Étoile, France) and presented yeast in Gram staining were included in the study.

\section{Direct GT}

From each blood culture bottle, $10 \mathrm{ml}$ of aspirate was transferred to a sterile $15 \mathrm{ml}$ polypropylene tube. After centrifugation at $4,000 \times \mathrm{g}$ for 10 minutes, the supernatant was removed. A $0.5 \mathrm{ml}$ sample was taken from the precipitate at the bottom of the tube and inoculated in a tube containing $0.5 \mathrm{ml}$ of human plasma to prepare a yeast suspension. The suspension was incubated at 37 ${ }^{\circ} \mathrm{C}$ for 2 hours. After incubation, one drop of the suspension was examined under a microscope for the presence of germ tube formation. 


\section{Conventional GTT from Standard Culture}

All blood culture bottles were seeded on Sabouraud dextrose agar (SDA) and the agents were isolated. Conventional GT was performed. In this test, several yeast colonies were added to $1 \mathrm{ml}$ of human serum, which was incubated at $37^{\circ} \mathrm{C}$ for $2-3$ hours, then examined for germ tube formation under a microscope ${ }^{[11]}$.

\section{Identification}

All isolates were identified using the mass spectrophotometer method (VITEK MS bioMérieux, Marcy-l'Étoile, France) and antifungal susceptibility tests were performed with the VITEK $2^{\circledR}$ automated system (bioMérieux, Marcy-l'Étoile, France). Antifungal susceptibility was determined using the criteria in the Clinical Laboratory Standards Institute (CLSI) M27-A3 guideline for amphotericin B and flucytosine susceptibility and the CLSI M27-S4 guideline for fluconazole, voriconazole, and caspofungin susceptibility ${ }^{[12,13]}$.

\section{Results}

Yeast cells were detected by Gram staining in 129 blood cultures that tested positive in automated blood culturing. In 57 of these (44.2\%), the agent was identified as C. albicans using the VITEK MS. Conventional GT was positive for all isolates identified as C. albicans. Direct GT from blood culture was positive for 54 (94.73\%) of these isolates and yielded false negative results in the other three samples (5.27\%). Agreement between conventional GT and direct GT from blood culture bottles was 97.6\% (126/129) (Table 1).

All of the 72 samples with negative results from direct GT from blood culture bottles yielded non-albicans Candida species. Results of conventional GT were also negative for all of these isolates. According to identification by VITEK MS, 43 of these isolates were $C$. parapsilosis, 17 were $C$. tropicalis, seven were $C$. famata, four were C. glabrata, and one was C. lipolytica (Table 2). The antifungal susceptibility test results obtained with the VITEK $2^{\circledR}$ automated system for all cultured yeasts are given in Table 3.

\section{Discussion}

Table 1. Comparison of the results of conventional germ tube test and germ tube test performed directly from blood culture bottles

\begin{tabular}{l|l|l|l|l|l}
\hline \multirow{2}{*}{ Test } & Positive & Negative & \multicolumn{2}{|l|}{ False negative } & Total \\
\cline { 2 - 6 } & $\mathbf{n}$ & $\mathbf{n}$ & $\mathbf{n}$ & $\%$ & \\
\hline $\begin{array}{l}\text { Conventional } \\
\text { GT }\end{array}$ & 57 & 72 & - & 0 & 129 \\
\hline Direct GT & 54 & 72 & 3 & 5.3 & 129 \\
\hline
\end{tabular}

GT: Germ tube test
Bloodstream infections caused by Candida species are associated with high mortality and morbidity in intensive care patients and immunocompromised patients ${ }^{[14,15]}$. The delay of appropriate antifungal therapy may increase the risk of mortality ${ }^{[1,16,17]}$. Patients that develop candidemia require immediate antifungal treatment. Identifying the species of Candida isolates is important when selecting an appropriate antifungal agent due to their varying drug susceptibilities ${ }^{[16]}$. Local epidemiology and resistance profiles should be considered when selecting antifungals $s^{[0]}$.

Performing GT directly from a positive blood culture bottle after detecting yeast with Gram staining (without waiting for growth on SDA, may provide a 24-hour advantage in the albicans/non-albicans differential ${ }^{[10]}$. This period may be a vital medical advantage in some cases. Of the 169 Candida strains isolated from blood cultures in our hospital, $53.5 \%$ were $C$. albicans and 46.5\% were non-albicans Candida ${ }^{[18]}$.

Unlike other studies in the literature, we performed the added step of centrifuging the samples taken from the blood culture bottles ${ }^{[10,17,18,20]}$. With this modification, we concentrated the yeast cells found in the blood cultures in order to obtain more accurate results from all bottles, which contained yeast at varying concentrations. We believe that the high agreement ( 95\%) between conventional GT and direct GT from blood cultures in this study was due in part to this modification. However, a high degree of consistency between the two methods ( $97-98 \%)$ has also been reported in some previous studies despite the absence of this centrifugation step ${ }^{[10,20]}$. Some other studies also reported lower levels of agreement (87-90\%) between the two methods, and we noted that all but one of those studies ${ }^{[19]}$ had smaller sample sizes compared to our study ${ }^{[19-21]}$.

A study by Terlecka et al. ${ }^{[10]}$ analyzed a total of 31 blood culture bottles with yeast growth, and with the exception of one $C$. albicans isolate with negative direct $\mathrm{G} \Pi$, agreement with conventional GT was $96.7 \%$ (30/31). In a study by Sheppard et al. ${ }^{[21]}, 63$ of 67 blood cultures with yeast growth were correctly identified by direct GT ( $94 \%$ consistency) and the four $C$. albicans strains with negative direct GT results were found to

Table 2. Distribution of Candida species isolated from blood cultures and identified with VITEK MS system

\begin{tabular}{l|l|l}
\hline Species & $\mathbf{n}$ & \% \\
\hline Candida albicans & 57 & 44.2 \\
\hline Candida tropicalis & 17 & 13.2 \\
\hline Candida glabrata & 4 & 3.1 \\
\hline Candida famata & 7 & 5.4 \\
\hline Candida parapsilosis & 43 & 33.3 \\
\hline Candida lipolytica & 1 & 0.8 \\
\hline Total & 129 & 100
\end{tabular}


Table 3. Rates of resistance to antifungal drugs among the Candida isolates

\begin{tabular}{|c|c|c|c|c|c|c|c|c|c|c|c|c|c|}
\hline \multirow{3}{*}{ Isolate } & \multirow{3}{*}{ n (\%) } & \multicolumn{12}{|c|}{ Antifungal drugs } \\
\hline & & \multicolumn{2}{|c|}{ Amphotericin B } & \multicolumn{2}{|c|}{ Fluconazole } & \multicolumn{2}{|c|}{ Flucytosine } & \multicolumn{2}{|c|}{ Voriconazole } & \multicolumn{2}{|c|}{ Capsofungin } & \multicolumn{2}{|c|}{ Micafungin } \\
\hline & & $\mathbf{n}$ & $\%$ & $\mathbf{n}$ & $\%$ & $\mathbf{n}$ & $\%$ & $\mathbf{n}$ & $\%$ & n & $\%$ & $\mathbf{n}$ & $\%$ \\
\hline Candida albicans & $57(44.2)$ & 2 & 3.5 & 3 & 5.2 & 1 & 1.7 & 5 & 8.7 & 1 & 1.7 & 1 & 1.7 \\
\hline Candida parapsilosis & 43 (33.3) & 4 & 9.3 & 14 & 32.5 & 2 & 4.6 & 3 & 6.9 & 2 & 4.6 & 1 & 2.3 \\
\hline Candida tropicalis & $17(13.2)$ & 2 & 11.7 & 3 & 17.6 & 2 & 11.7 & 1 & 5.8 & 3 & 17.7 & 3 & 17.7 \\
\hline Candida lipolytica & $1(0.8)$ & 0 & 0 & 1 & 100 & 0 & 0 & 0 & 0 & 0 & 0 & 0 & 0 \\
\hline Candida glabrata & $4(3.1)$ & 1 & 25 & 2 & 50 & 0 & 0 & 1 & 25 & 1 & 25 & 1 & 25 \\
\hline Candida famata* & $7(5.4)$ & - & - & - & - & - & - & - & - & - & - & - & - \\
\hline Total & 129 & 9 & 6.9 & 23 & 24.8 & 5 & 3.8 & 10 & 7.7 & 7 & 5.4 & 6 & 4.6 \\
\hline
\end{tabular}

*Susceptibility testing cannot be performed for Candida famata with the VITEK $2^{\circledR}$ automated system

be slow-growing. In another study, Saad et al. ${ }^{[22]}$ reported 100\% agreement between conventional and direct GT performed with 100 blood cultures with yeast growth. The lowest rate of agreement between the two methods that we found in the literature was $87.8 \%(151 / 172)^{[19]}$. In the present study, we determined a $97.6 \%(126 / 129)$ rate of agreement between direct GT from blood culture bottles with yeast growth and conventional identification tests. It is clear that agreement between the methods is quite high, with low false-negative rates. In fact, the main disadvantage of direct GT from blood culture is these false negative results ${ }^{[23]}$. As in our study, no false positives have been reported in the literature for direct GT performed from blood culture bottles. However, false-positive/ negative $\mathrm{G} T$ results can be obtained in cases of polymicrobial candidemia, which is caused by more than one species. In such cases, the result needs to be confirmed by culture or another method $^{[19]}$.

Apart from GT, different methods can also be used for the rapid identification of Candida species. For example, Kassim et al. ${ }^{[23]}$ found no significant difference between VITEK 2 and MALDI TOF in terms of Candida species. In a study by Doğan et al. ${ }^{[19]}$, chromogenic agar media were used for rapid identification. However, the authors stated that this method involved higher costs and a longer time, and that a specific color might not be detected for some Candida species. The direct GT procedure is much faster and more cost-effective than these methods because it omits the culture step.

While echinocandins are the first choice for empirical treatment, fluconazole is recommended for $C$. albicans when the agent is identified ${ }^{[24]}$. These are also the treatment regimens used in our hospital. However, non-albicans Candida species show higher levels of resistance to azole antifungals and fluconazole ${ }^{[25,26]}$. In a study by Chi et al. ${ }^{[25]}$, susceptibility rates identified for nonalbicans Candida species were 91.5\% for fluconazole and 95.7\% for voriconazole. Whaley et al. ${ }^{[26]}$ reported resistance rates of 2.3-96.6\% against fluconazole alone. As can be observed from Table 3, higher resistance rates were detected for nonalbicans Candida species against azoles (fluconazole: $5.2 \%$ in $C$. albicans isolates and 17.6-100\% in non-albicans Candida species; voriconazole: $8.7 \%$ in C. albicans isolates and $5.8-25 \%$ in nonalbicans Candida species). C. albicans isolates have low levels of fluconazole and voriconazole resistance (Table 3). Tulumoğlu et al. ${ }^{[27]}$ also reported resistance rates similar to our findings (fluconazole: $3.63 \%$; voriconazole: $5.45 \%$ ). Due to these resistance profiles, direct $\mathrm{G} \Pi$ result may provide significant advantages in terms of preventing inappropriate empirical treatment. When a report of albicans or non-albicans is provided to the clinic, a more appropriate antifungal treatment can be initiated based on resistance rates. Furthermore the initiation of inappropriate antifungal treatment and the use of azole class drugs to treat non-albicans candidemia may lead to the development of resistant Candida and the development of resistance during treatment ${ }^{[8]}$. At our hospital, direct GT result from the bottle is also considered when selecting an antifungal drug for patients with suspected candidemia. Fluconazole is preferred for patients with positive direct $G \Pi$ results while echinocandins are preferred instead of azoles in order to target non-albicans species for patients with negative GTT results.

Limitations of this study include its retrospective nature, the absence of more detailed clinical data and treatment success rates, and the fact that antifungal susceptibility tests were only performed with an automated system.

\section{Conclusion}

In conclusion, performing direct GTT from positive blood culture bottles that present yeast in Gram staining allows differentiation between albicans and non-albicans Candida species a day earlier than routine culture methods and shows strong agreement with conventional diagnostic tests. It should be kept in mind that this method may yield false negative results, but the rate is very low. This test may enable empirical treatment to be initiated earlier and with a more appropriate antifungal agent. In addition, this 
method is easy and can be applied at all clinical microbiology laboratories.

\section{Ethics}

Ethics Committee Approval: This study was approved by the Ethics Committee of Sakarya University Medical Faculty (approval no: 71522473/050.01.04/67).

Informed Consent: Since this was a retrospective laboratory based study informed consent was not received.

Peer-review: Externally and internally peer-reviewed.

\section{Authorship Contributions}

Surgical and Medical Practices: O.K., Concept: M.K., Design: T.D., K.Y., H.H., Data Collection or Processing: Ü.K., K.Y., Analysis or Interpretation: H.H., K.Y., Ü.K., Literature Search: K.Y., H.H., Writing: M.A., M.K., T.D.

Conflict of Interest: No conflict of interest was declared by the authors.

Financial Disclosure: The authors declared that this study received no financial support.

\section{References}

1. Falagas ME, Apostolou KE, Pappas VD. Attributable mortality of candidemia: a systematic review of matched cohort and case-control studies. Eur J Clin Microbiol Infect Dis. 2006;25:419-25.

2. Zilberberg MD, Shorr AF, Kollef MH. Secular Trends in Candidemia-Related Hospitalization in the United States, 2000-2005. Infect Control Hosp Epidemiol. 2008;29:978-80.

3. Pappas PG, Rex JH, Lee J, Hamill RJ, Larsen RA, Powderly W, Kauffman CA, Hyslop N, Mangino JE, Chapman S, Horowitz HW, Edwards JE, Dismukes WE; NIAID Mycoses Study Group. A prospective observational study of candidemia: epidemiology, therapy, and influences on mortality in hospitalized adult and pediatric patients. Clin Infect Dis. 2003;37:634-43.

4. Krcmery V, Barnes AJ. Non-albicans Candida spp. causing fungemia: pathogenicity and antifungal resistance. J Hosp Infect. 2002;50:243-60.

5. Ghannoum MA, Roilides E, Katragkou A, Petraitis V, Walsh TJ. The role of echinocandins in Candida biofilm-related vascular catheter infections: in vitro and in vivo model systems. Clin Infect Dis. 2015;61(Suppl 6):618-21.

6. Dimopoulos G, Ntziora F, Rachiotis G, Armaganidis A, Falagas ME. Candida albicans versus non-albicans intensive care unit-acquired bloodstream infections: differences in risk factors and outcome. Anesth Analg. 2008;106:523-9.

7. Garey KW, Rege M, Pai MP, Mingo DE, Suda KJ, Turpin RS, Bearden DT. Time to initiation of fluconazole therapy impacts mortality in patients with candidemia: a multi-institutional study. Clin Infect Dis. 2006;43:25-3.

8. Shorr AF, Lazarus DR, Sherner JH, Jackson WL, Morrel M, Fraser VJ, Kollef MH. Do clinical features allow for accurate prediction of fungal pathogenesis in bloodstream infections? Potential implications of the increasing prevalence of non-albicans candidemia. Crit Care Med. 2007;35:1077-83.

9. Hankovszky P, Trasy D, Öveges N, Molnar Z. Invasive Candida infections in the ICU: Diagnosis and therapy. J Crit Care Med (Targu Mures). 2015;1:129-39.

10. Terlecka JA, du Cros PA, Morrissey CO, Spelman D. Rapid differentiation of Candida albicans from non-albicans species by germ tube test directly from BacTAlert blood culture bottles. Mycoses. 2007;50:48-51.
11. Salazar JM, Rojas R. Comparative study for identification of Candida albicans with germ tube test in human serum and plasma. Clinical Microbiology and Infectious Diseases. 2018;3:1-4.

12. Clinical and Laboratory Standards Institute (CLSI). Reference method for broth dilution antifungal susceptibility testing of yeasts; fourth informational supplement. Wayne: Clinical and Laboratory Standards Institute; 2012 (Document M27-S4).

13. Clinical and Laboratory Standards Institute (CLSI). Reference method for broth dilution antifungal susceptibility testing of yeasts. $3^{\text {rd }}$ ed. Wayne: Clinical and Laboratory Standards Institute; 2008 (Approved standard M27-S3).

14. Barchiesi F, Orsetti E, Gesuita R, Skrami E, Manso E; Candidemia Study Group. Epidemiology, clinical characteristics, and outcome of candidemia in a tertiary referral center in Italy from 2010 to 2014. Infection. 2016;44:205-13.

15. Diekema D, Arbefeville S, Boyken L, Kroeger J, Pfaller M. The changing epidemiology of healthcare-associated candidemia over three decades. Diagn Microbiol Infect Dis. 2012;73:45-8.

16. Cornely $\mathrm{OA}$, Bassetti $M$, Calandra $T$, Garbino J, Kullberg BJ, Lortholary 0 , Meersseman W, Akova M, Arendrup MC, Arikan-Akdagli S, Bille J, Castagnola E, Cuenca-Estrella M, Donnelly JP, Groll AH, Herbrecht R, Hope WW, Jensen HE, Lass-Flörl C, Petrikkos G, Richardson MD, Roilides E, Verweij PE, Viscoli C, Ullmann AJ; ESCMID Fungal Infection Study Group. ESCMID* guideline for the diagnosis and management of Candida diseases 2012: non-neutropenic adult patients, Clin Microbiol Infect. 2012;18(Suppl 7):19-37.

17. Kollef M, Micek S, Hampton N, Doherty JA, Kumar A. Septic shock attributed to Candida infection: importance of empiric therapy and source control. Clin Infect Dis. 2012;54:1739-46.

18. Aydemir Ö, Demiray $T$, Köroğlu $M$, Aydemir $Y$, Altındiş $M$. Emerge of nonalbicans Candida species; evaluation of Candida species and antifungal susceptibilities according to years. Biomedical Research. 2017;28:1-6.

19. Doğan Ö, Gülmez D, Arıkan Akdağlı Arıkan S. A Fast Preliminary Identification Test in Fungemia: Evaluation of Germ Tube Test Directly from Positive Blood Culture Bottles. Ankem Derg. 2016;30:102-8.

20. Gokbolat $\mathrm{E}, \mathrm{Oz} Y$, Metintas $\mathrm{S}$. Evaluation of three different bottles in BACTEC 9240 automated blood culture system and direct identification of Candida species to shorten the turnaround time of blood culture. J Med Microbiol. 2017;66:470-6.

21. Sheppard DC, Locas MC, Restieri C, Laverdiere M. Utility of the germ tube test for direct identification of Candida albicans from positive blood culture bottles. J Clin Microbiol. 2008;46:3508-9.

22. Saad U, Siddiqui S, Jamil N, Jamil S, Hafiz S. Detection of Candida albicans from Positive Blood Culture Bottles. Int J Pathol. 2013;11:54-7.

23. Kassim A, Pflüger V, Premji Z, Daubenberger C, Revathi G. Comparison of biomarker based Matrix Assisted Laser Desorption lonization-Time of Flight Mass Spectrometry (MALDI-TOF MS) and conventional methods in the identification of clinically relevant bacteria and yeast. BMC Microbiol. 2017;17:128.

24. Pappas PG, Kauffman CA, Andes DR, Clancy CJ, Marr KA, Ostrosky-Zeichner L, Reboli AC, Schuster MG, Vazquez JA, Walsh TJ, Zaoutis TE, Sobel JD. Clinical Practice Guideline for the Management of Candidiasis: 2016 Update by the Infectious Diseases Society of America. Clin Infect Dis. 2016;62:1-50.

25. Chi HW, Yang YS, Shang ST, Chen KH, Yeh KM, Chang FY, Lin JC. Candida albicans versus non-albicans bloodstream infections: the comparison of risk factors and outcome. J Microbiol Immunol Infect. 2011;44:369-75

26. Whaley SG, Berkow EL, Rybak JM, Nishimoto AT, Barker KS, Rogers PD. Azole antifungal resistance in Candida albicans and emerging Non-albicans Candida species. Front Microbiol. 2016;7:2173

27. Tulumoğlu Ş, Kariptaş E, Belgin E. Identification and antifungal susceptibility of Candida isolates from various clinical specimens in Doctor Behcet $\mathrm{Uz}$ Hospital. Anatol J Clin Invest. 2009;3:170-3. 